\author{
Alicja Korzeniecka-Bondar \\ Uniwersytet w Białymstoku \\ e-mail: alibon@uwb.edu.pl
}

\title{
O trudnościach w pisaniu - uwagi na marginesie lektury tekstów przesłanych do redakcji „Parezji”
}

Doskonalenie rzemiosła pisarskiego to wyzwanie na całe $\dot{z} y$ cie, a błędy są nieodłączną częścią tej gry (Pinker, 2015)

\section{STRESZCZENIE}

Celem artykułu jest ukazanie błędów w pisaniu zauważonych w maszynopisach przesyłanych do redakcji „Parezji”. Wyróżniono błędy o charakterze: poznawczym, strukturalnym, pragmatycznym, stylistycznym i formalnym. Wskazano na potrzebę namysłu wielokrotnego w trakcie procesu tworzenia tekstu oraz na wartość wspólnot naukowych, w których troszczy się o kształtowanie u młodych adeptów pedagogiki etosu rzetelnej pracy nad własnym warsztatem pisarskim.

SŁOWA KLUCzowe: pisarstwo naukowe, błędy poznawcze, błędy formalne, namysł wielokrotny

\section{Wprowadzenie}

Tekst jest zaadaptowanym do druku wystąpieniem z XXXI Letniej Szkoły Młodych Pedagogów, która była poświęcona tematyce problemów z własnym lub cudzym warsztatem pisarstwa naukowego․ Pragnąc skorzystać z okazji zabrania głosu w tak istotnej sprawie, posłużyłam się doświadczeniem płynącym z bycia redaktor naczelną półrocznika „Parezja. Czasopisma Forum Młodych Pedagogów przy Komitecie Nauk Pedagogicznych PAN”. Czteroletnie doświadczenie („Parezja” wydawana jest od 2014 roku) nie uprawnia do udzielania rad czy tworzenia kompendium wiedzy o pisarstwie naukowym. W tym zakresie znaleźć można bogatą literaturę znawców zagadnienia (Eco,

XXXI Letnia Szkoła Młodych Pedagogów organizowana była przez Komitet Nauk Pedagogicznych PAN we współpracy z Wydziałem Nauk Pedagogicznych Uniwersytetu Kardynała Stefana Wyszyńskiego w Warszawie pod kierownictwem naukowym prof. dr hab. Marii Dudzikowej - szerzej w Sprawozdaniu ze Szkoły zamieszczonym w tym numerze „Parezji”. 
2007; Becker, 2013; Pinker, 2015). Mój zamiar jest skromny - chcę podzielić się uwagami płynącymi z redagowania czasopisma naukowego, w którym publikują zwłaszcza młodzi badacze. Wypowiedź nie jest dogłębną analizą przesłanych do redakcji tekstów, uwzględniającą ich zróżnicowanie w zakresie treści czy formy. Są to jedynie uwagi na marginesie lektury, o czym informuję w tytule, mające na celu ukazanie trudności/błędów w pisaniu zauważonych w maszynopisach przesyłanych do redakcji.

Oglądu trudności w pisaniu dokonam z dwóch względów: po pierwsze, „Parezja” jest czasopismem naukowym Forum Młodych Pedagogów (Tołwińska, 2014), tworzonym z myślą o autorach z niewielkim doświadczeniem, znajdujących się na początku drogi naukowej. Rozpoznanie trudności pisarskich, z którymi borykają się inni autorzy, może uchronić ich przed popełnieniem podobnych $\mathrm{w}$ trakcie realizacji własnych projektów.

Po wtóre, swoją wypowiedź traktuję jako głos w dyskusji nad jakością publikacji w obrębie pedagogiki. Jako pracownicy uczelni poddawani jesteśmy regularnej ocenie, której głównym kryterium jest liczba (najlepiej wysoko punktowanych) publikacji. Sytuacja taka sprawia, że wielu autorów porywa się i/lub jest zobowiązywana do jak największej ich „produkcji”. A to często idzie w parze $\mathrm{z}$ ich niską jakością. Wymóg tempa i ilości kłóci się z długotrwałym, wielokrotnym namysłem nad tworzonymi projektami. Dotyka to w największym stopniu młodych badaczy, którzy z jednej strony są zbyt młodzi, by pamiętać inną kulturę pracy nad tekstem, gdzie liczyła się jakość i treść wypowiedzi; z drugiej często nie mają nauczycieli, którzy chcieliby zaszczepiać im taki etos pracy (Dudzikowa, Bochno, Grzybowski, Kola, Korzeniecka-Bondar, Kin-Wiśniewska, 2013). Zdarza się, że traktują taki sposób funkcjonowania jako oczywisty i niekwestionowany element własnego funkcjonowania na uczelni. Godzą się na bycie „maszynką produkującą" tekst za tekstem, podtrzymując tym samym (często nieświadomie!) koncepcję uniwersytetu jako firmy wydajnie produkującej informacje (por. Nawrocki, 2016).

Spojrzę na nadesłane teksty $\mathrm{z}$ kilku perspektyw wyróżnionych przez Marię Wojtak, specjalistkę z zakresu genologii, stylistyki i języka mediów. Autorka uważa gatunki wypowiedzi za „modele organizacji tekstu, czyli byty abstrakcyjne zorganizowane wewnętrznie we wzorcach obejmujących cztery płaszczyzny: a) strukturę (granice tekstów, ich segmentację i relacje między segmentami), b) aspekt poznawczy (tematykę i sposób jej prezentacji, perspektywę, punkt[y] widzenia, aksjologię), c) pragmatykę (obraz nadawcy i odbiorcy wpisany w tekst, relacje nadawczo-odbiorcze, potencjał illokucyjny, czyli zbiór intencji oraz sposób ich uporządkowania), d) stylistykę (zbiór 
cech ekstralingwistycznych determinowanych strukturą, dookreślonych poznawczo i pragmatycznie oraz odpowiadający im zbiór środków stylistycznych, w tym form nacechowanych trwale, więc kodowo, co się odzwierciedla w stosownych kwalifikacjach leksykograficznych)" (Wojtak, 2014, s. 63-64). Wyróżnionych płaszczyzn nie traktuję rozłącznie, gdyż w konkretnym tekście nachodzą one na siebie. Posłużyły mi one do pogrupowania dostrzeżonych błędów w maszynopisach przesłanych do „Parezji”. Oglądowi poddaję prace wielokrotnie odsyłane autorom do poprawy oraz odrzucone na etapie recenzji wewnętrznej lub zewnętrznej. W swoich analizach korzystam także z uwag i zaleceń sformułowanych przez recenzentów.

Zanim przejdę do omówienia dostrzeżonych błędów, pragnę jeszcze ostrzec Czytelnika przed mogącym się zrodzić przekonaniem, że wyróżniam coś takiego, jak błędy w „tekstach w ogóle”. Tekst zawsze przynależy do określonego rodzaju, gatunku oraz odmiany wypowiedzi. Omówienie poszczególnych gatunków wypowiedzi oraz popełnianych w nich błędów wykracza poza możliwości zarówno tego tekstu, jak i moje. A zatem - moje uwagi będą miały, w wielu miejscach, charakter uogólnień formułowanych jednak ze świadomością istnienia różnorodności gatunków wypowiedzi (Wojtak, 2014a). Spodziewając się wśród Czytelników osób, które nie znają rodzajów publikacji prasowych, przywołuję je, zachęcając do samodzielnego zapoznania się z regułami ich tworzenia. W. Furman, A. Kaliszewski i K. Wolny-Zmorzyński dokonują podziału publikacji prasowej, w układzie trychotomicznym (przytaczam wybrane przykłady gatunków): 1) rodzaj informacyjny, z gatunkami: wzmianka, zapowiedź, sprawozdanie, relacja, raport, korespondencja, życiorys, przegląd prasy; 2) rodzaj publicystyczny, z gatunkami: artykuł, artykuł wstępny, felieton, komentarz, recenzja, esej, dziennik, nekrolog); 3) rodzaj informacyjno-publicystyczny, z gatunkami: wywiad, debata, list do redakcji, odpowiedź na list do redakcji (Wolny-Zmorzyński, Kaliszewski, Furman, 2006, s. 34). Maria Wojtak dzieli się swoim spostrzeżeniem, które warto przemyśleć w kontekście omawianych kwestii jako przestrogę, ale i zachętę do zapoznawania się z literaturą z językoznawstwa. Oto ona: „[n]ieznajomość rodzajów, gatunków i odmian gatunkowych wypowiedzi stosowanych w czasopismach pociąga za sobą nieznajomość reguł pisania tekstów w określonej konwencji. W obecnej dobie, w różnych przestrzeniach komunikacyjnych mamy do czynienia z naruszaniem reguł wzorców gatunkowych wypowiedzi, z interferencjami gatunkowymi, które nie zawsze sprzyjają skutecznemu i stosownemu komunikowaniu się" (Wojtak, 2014, s. 65). 


\section{Błędy/trudności dostrzeżone w maszynopisach}

W maszynopisach przesyłanych do „Parezji” dostrzegłam najwięcej błędów poznawczych, dotyczących treści wypowiedzi. Postaram się je szerzej omówić, ilustrując (gdzie to będzie możliwe) stosownymi przykładami. Brak wiedzy na dany temat jest najczęstszym powodem odrzucania przez recenzentów przesłanych prac. Niedostatek wiedzy skutkuje brakiem pogłębionej refleksji i analizy. Autor „odkrywa” to, co dla znawców zagadnienia jest banalne i nic niewnoszące. „Wciska kit” - mówiąc za Harrym G. Frankfurtem (2008), o czym szeroko w kontekście analizy dyskursu pedagogicznego pisała Maria Dudzikowa (2009). PRZYKŁAD²:

Wychowanie jest jednym z podstawowych czynników kształtujących młodego człowieka. Wiodaca rolę w tym procesie odgrywaja rodzice, a w późniejszym etapie nauczyciele. Poprzez modelowanie dorosty staje się wzorcem określonych zachowań, wskazuje sposoby postępowania w różnorodnych sytuacjach. Bez takich czytelnych wzorców dziecko gubiłoby się w gąszczu wieloznaczności i różnorodności [...].

Autor porusza tematykę powszechnie znaną, nabywaną w rezultacie potocznego oglądu świata.

Niski stan wiedzy obnażają lektury, z których autor korzysta. Są one zwykle: wprowadzające, nieaktualne, dobrane w niejasny sposób. Autor nie podejmuje pogłębionych studiów nad danym zagadnieniem, gdyż wymaga to sukcesywnego gromadzenia literatury, wielokrotnego namysłu nad kryteriami ich doboru czy celowością użycia. Takie teksty nie wyrastają $\mathrm{z}$ aktualnego stanu wiedzy i umiejętnego korzystania $\mathrm{z}$ dorobku przeszłości (Lewowicki, 2016), są raczej przeglądem tego, co „ma się pod ręką”. Zdarza się, że tekst posiada bogatą bibliografię, jednak prowadzona analiza nie wskazuje na jej wykorzystywanie. Autor dobiera lektury, kierując się często wyłącznie ich tytułami, a w najlepszym razie wycinając co efektowniejsze cytaty, które komponuje w dowolny sposób. Nie pisze dlatego, że ma coś ważnego do powiedzenia. Powodem jest chęć lub konieczność opublikowania „czegoś”.

Zdarza się, że autor sili się na napisanie tekstu specjalnie „pod tematykę" konkretnego numeru czasopisma, nawet gdy nie jest to „jego kawałek podłogi”. Przykładem jest tekst pod tytułem: WsPó£CZESNY NAUCZYCIEL WOBEC PROBLEMU PAREZJI. Autor ewidentnie nie znając się na problematyce zaprojektował badania, w których zadaje pytania typu: „Czy w opinii nauczycieli,

2 Przykłady zostały zapisane kursywą. Staram się zachować anonimowość autorów, w tym celu w niektórych wykorzystywanych przykładach usuwam fragmenty wypowiedzi. Nie dokonuję korekty błędów, niedociągnięć. W bibliografii własnego tekstu nie przywołuję prac, z których korzystali autorzy. 
przyjmuja oni postawę parezjasty wobec działań władz oświatowych? Czy nauczyciele tworza grupe społeczna, która ma moc decyzyjna? [...]". W ten sposób chciał - na co wskazuje cel badań - „przedstawić opinie nauczycieli wobec parezji w realiach polskiej rzeczywistości edukacyjnej”. Sformułowane pytania nie dawały możliwości realizacji założonego celu. Nieznajomość tematu, wespół z nieprawidłowo przeprowadzonymi badaniami, dyskwalifikują tekst, wskazują na niewiedzę badającego. W takiej sytuacji ważną rolę odgrywają recenzenci, których merytoryczne uwagi mogą stać się dla autora bodźcem do pracy nad sobą. Nie wszystkie nieprawidłowo przeprowadzone badania wyłapywane są gęstym „sitem recenzyjnym”. Młodzi adepci nauki mają trudność rozpoznania prac wartych czytania i tych, których należy unikać. Redakcja „Parezji” odrzuciła poprawnie przygotowaną pod względem formalnym recenzję, gdyż dotyczyła książki zawierającej liczne błędy metodologiczne. Na marginesie tylko dodam, że recenzję przygotowała osoba zatrudniona $\mathrm{w}$ tej samej jednostce naukowej, co autor, a na dodatek mu podległa. Autor wpada w pułapkę swojej niewiedzy i przekonania, że „byle czego się nie piszą" (Redliński, 1973, s. 111), a napisane oznacza wartościowe, co w Konopielce Edwarda Redlińskiego zaszczepiał ojciec synowi.

Są autorzy, którzy zatrzymali się na pewnym poziomie pisania tekstów, trzymają się działań nawykowych, pomimo konkretnych wskazań i uwag recenzentów. Taki autor nie uczy się, nie zastanawia, co „idzie” za wskazanym przez nich tropem, uparcie trzyma się swoich schematów, nawyków. Na tę pułapkę inercji mentalnej zwracałam uwagę, pisząc o potrzebie namysłu wielokrotnego (Korzeniecka-Bondar, 2017). Te utarte schematy i przyzwyczajenia dotyczą także tematyki poruszanej w tekstach. „Parezja” jest czasopismem tematycznym, skupionym wokół konkretnej kluczowej kategorii; przykładowe to: parezja, upokorzenie, nieposłuszeństwo, irytacja. Proponowane kategorie wydają się nośne i otwierające na analizy dotyczące aktualnej rzeczywistości. Mało jest jednak tekstów dotyczących ważnych problemów dziejących się „tu i teraz", w których autorzy artykułują, co ich irytuje, inspiruje, niepokoi itd. Zwykle dany autor analizuje zagadnienia przebadane, bezpieczne, choć mało aktualne, podejmuje tematy zgodne z mainstreamowymi oczekiwaniami. Pisze tekst „wypreparowany” z kontekstu teraźniejszych zdarzeń, nie problematyzuje ich. Inaczej mówiąc: mimo iż w obszarze szeroko pojętej edukacji wskazać można wiele spraw bulwersujących, budzących krytykę, wymagających zajęcia stanowiska, nie można dostrzec tego w nadsyłanych tekstach.

Częstym błędem piszących do „Parezji” jest nic niemówiący abstrakt. Autor pisze go, jak określa Emanuel Kulczycki, „na czuja”, traktując jako „mały i nieistotny element całego artykułu i procesu pisania” (Kulczycki, 
2013), bez świadomości, że często to na ich podstawie tekst zostaje zaliczony do wartych lub niewartych przeczytania. PRZYKŁAD:

Życie człowieka jest ciagłym procesem realizowania wartości, które odzwierciedlaja sens, sposób funkcjonowania w świecie i myślenia o nim. Bardzo często kojarza się z pewnymi drogowskazami, którymi powinno się w życiu kierować. Sa abstrakcyjnymi pojęciami pokazującymi, co jest dobre, słuszne, ogólnie pożądane oraz stanowia podstawe oceny społecznych działań człowieka a także kształtuja i wpływaja na podejmowane przez niego wybory. To właśnie „człowiek buduje siebie, świat a w ten sposób wciela $w$ życie wartości. Dzięki niemu to, co cielesne i materialne, staje się duchowe, cenne, wartościowe". Preferowany system wartości zależy od konkretnej jednostki. Dla jednych ma większe znaczenia, dla innych jest mało istotny i znaczacy. Cenione kiedyś wartości tradycyjne - „Bóg, Honor, Ojczyzna” uległy recesji oraz wykreowały w społeczeństwie nihilizm i sceptycyzm. Uznawany kanon średniowiecznego rycerza niewątpliwie stopniowo ustępuje miejsca wartościom konsumpcyjnym, instrumentalnym. Szczególnie widoczne staje się to u osób młodych, którzy coraz częściej prezentują brak rzeczywistego uznania dla wartości wyższych.

Przytoczony abstrakt stanowi luźne refleksje o wartościach i ich roli w życiu człowieka, w ogóle nie informuje zaś o zawartości tekstu. Nie uzasadnia, czego można dowiedzieć się, analizując określoną kwestię oraz dla kogo jest to ważne. Autor nie formułuje pytań, na które poszukuje odpowiedzi, nie określa co, w jakim wymiarze i w jakim celu analizuje. Inaczej mówiąc, nie zakreśla pola problemowego, które za H. Girouxem rozumiem jako „konceptualną strukturę, identyfikowaną zarówno przez pytania, jakie [autor - dop. A. K-B] stawia, oraz pytania, których nie jest w stanie sformułować" (Giroux, 1993, s.107). Sytuacja taka sprawia, że pisze o wszystkim, o zbyt wielu wątkach równocześnie.

Wiąże się to zwykle z nieczytelną strukturą tekstu - błędem, o charakterze strukturalnym, często zauważanym w przesłanych maszynopisach. Autor nie zapowiada struktury i/lub pisze „ciurkiem”, bez zaznaczenia śródtytułami kluczowych części. Autor nie deklaruje, z ilu części składa się tekst i nie prowadzi czytelnika po analizowanych wątkach. Brak wydzielonych czytelnie segmentów tekstu sprawia, że wątki się plączą. Świadczy to o braku logiki wypowiedzi i niewystarczającej refleksji nad kompozycją całości.

Struktura wypowiedzi determinuje jej stylistyczny aspekt. W przesłanych maszynopisach dostrzec można liczne trudności stylistyczne. PRZYKŁAD:

Moja irytacja bierze się z nierozumienia $z$ mody na COANCHING. Mimo (tak mi się wydaje) rzetelnego podejścia do tematu, moje nierozumienie poruszanej problematyki, bierze się zapewne z braku nie wystarczajacej wiedzy na dany temat. Jed- 
nak moja, jeżeli można tak ująć główna irytacja jest z tego powodu, że kiedy czytając, słysząc o coachingu i coauchu, zadaje sobie pytanie dlaczego znowu Mikołaj Rej ma rację? Nie jest to jakiś nacjonalizm, zwyczajne zadziwienie, nierozumienie, implikujące pytanie: Dlaczego wręcz z uwielbieniem "makaronizujemy” nasza rzeczywistość? Mówiąc dookoła, że owe zewnątrz w tym przypadku coaching, jest „innowacyjnym” rozwiązaniem na wiele trudnych spraw, w wielu różnorodnych instytucjach i wielu ludzi z przeróżnymi problemami. [...].

Autor w nieprawidłowy sposób formułuje myśli, dobiera i łączy wyrazy, np. „brak niewystarczającej wiedzy na dany temat; główna irytacja jest z tego powodu, że [...]". Konstruuje zdania wielokrotnie złożone o nielogicznym układzie, np. „Mówiąc dookoła, że owo zewnątrz, w tym przypadku coaching, jest «innowacyjnym» rozwiązaniem na wiele trudnych spraw, $w$ wielu różnorodnych instytucjach i wielu ludzi z przeróżnymi problemami”. Dostrzec można wielosłowie, używanie zbędnych wyrazów utrudniających rozumienie zdań, np. „Jednak moja, jeżeli można tak ująć [...]”. Nagminne jest mieszanie języka potocznego i pojęć naukowych, liczby pojedynczej i mnogiej. Pogrubione angielskojęzyczne słowo coach, nadużywane jest przez autora i dodatkowo nie zawsze poprawnie zapisywane. Ubóstwa słownictwa dowodzi nadużywanie zaimków. Te wskazane powyżej nieprawidłowości stylistyczne nie wyczerpują listy możliwych do wyłonienia w tym fragmencie błędów. Odsłaniają dodatkowo braki merytoryczne dotyczące niezrozumienia opisywanego zjawiska, nieumiejętnego definiowania użytych terminów itp.

Kolejnym błędem, tym razem o charakterze pragmatycznym, jest brak zdefiniowania odbiorcy tekstu - autor nie przewiduje czytelnika, do którego adresuje własną wypowiedź. Zakładam, że rozważania Umberta Eco (1987) dotyczące czytelnika modelowego i czytelnika empirycznego nie wszystkim mogą być znane, dlatego poświęcę im akapit. Ponownie posłużę się cytatem z Konopielki (Redliński, 1973, s. 111) - „pisanie to nie gadanie” ... i trzeba o tym pamiętać. Pisanie różni od komunikowania twarzą w twarz to, że piszący, operując słowami, nie może ich wzmocnić gestem, mimiką, mową ciała, a przede wszystkim nie uzyska od odbiorcy natychmiastowej informacji zwrotnej. Umberto Eco tłumaczy (1987, s. 291), że piszący, przewidując wspólny zasób wiedzy podzielany z odbiorcą (wyobrażając sobie czytelnika modelowego własnych tekstów), może w rzeczywistości rozminąć się z owym przewidywaniem. Wyobrażając sobie takiego czytelnika, zakłada, że „zbiór kompetencji, do którego się odwołuje, jest tym samym zbiorem, do którego odwołuje się jego czytelnik" (s. 292). Natomiast empiryczny czytelnik tekstu może nie znać kategorii wykorzystywanych przez autora, nie posiadać oczekiwanych kompetencji - mieć braki w zasobie wiedzy sprawiające, że 
nie odczyta wypowiedzi tak, jak zakłada nadawca (to oczywiście niejedyny powód rozbieżności).

Autor, nieświadom omówionych kwestii, nie nawiązuje kontaktu z czytelnikiem. Przejawia się to brakiem prowadzenia czytelnika przez tekst, zaniechaniem wyjaśniania, co, dlaczego oraz w jakiej kolejności robi. Pisze, nie przewidując reakcji czytelnika na obraną strategię prezentowania treści i jego intelektualnych zdolności do uczestniczenia w stylu, który proponuje. Inaczej mówiąc, nie zastanawia się, kim jest empiryczny czytelnik jego tekstów, jakie posiada oczekiwania i możliwości percepcyjne.

$\mathrm{Z}$ tym związany jest problem ujawniania się autora empirycznego (Eco, 1987). Są teksty, których cel zapowiada konieczność ujawnienia się autora empirycznego (np. raport z badań, esej, list do redakcji), ale wypowiedź jest tak skonstruowana, że trudno określić, kto nim jest. Pisze on $\mathrm{w}$ formie bezosobowej, np.: zbadano, rozpoznano, wskazano, lub używa liczby mnogiej (przy podanym jednym autorze), np.: zrobiliśmy, zbadaliśmy. Zdarza się, że autor nie wykracza poza cytowanie czyichś słów, argumentów, nie zabiera stanowiska w omawianej sprawie. Skleja fragmenty wypowiedzi innych, nie ukazując własnej intencji, autorskiego sposobu myślenia. Cytuje, jak powiada Maria Dudzikowa, „nożyczkami”, zniekształcając tym samym sens przywoływanych zdań.

Bywają autorzy, którzy nie zawiązują z czytelnikiem paktu faktograficznego, co Zbigniew Bauer tłumaczy jako zobowiązanie co do wierności przedstawianych faktów, szczegółowości i zwięzłości (Bauer, 2008). Autor, który nie troszczy się, by jego tekst w rzetelny sposób opisywał wycinek rzeczywistości, formułuje nieuzasadnione przypuszczenia i/lub niedowiedzione, w świetle prowadzonych badań, tezy. Kolekcjonuje fakty (bez poczucia odpowiedzialności za ich prawdziwość), opisuje je w sposób ogólnikowy, dokonuje nieuprawnionych wniosków. Nie informuje czytelnika, co dokumentuje formułowane tezy. Dane empiryczne z badań własnych lub innych badaczy, dane statystyczne, własne doświadczenia?

Ponadto często dostrzec można niedbałość autorów o przestrzeganie formalnych wymogów opracowania. Zaliczyć do nich można np.: brak staranności w przygotowaniu przypisów i bibliografii, nieczytelne opracowanie tabel, schematów, zbyt dużą liczbę spacji i enterów itp. Autor wysyła tekst do redakcji w przekonaniu, że on włożył wysiłek w przygotowanie części merytorycznej, a porządkowaniem strony formalnej zajmie się kto inny. Bywa nawet, że autor zaleca redakcji, by przed dalszym procedowaniem poddała maszynopis „obróbce językowej” lub innego rodzaju, co świadczy o uświada- 
mianiu sobie popełnianych błędów. Nie idzie to jednak w parze z dążeniem do ich wyeliminowania.

\section{Konkluzje}

Autorzy popełniają szereg błędów, które podzielić można na dwie grupy: dotyczące treści i formy. Powodów takiego stanu rzeczy jest wiele. Kluczowy wydaje się sposób kształcenia w szkole wyższej, jak i na wcześniejszych etapach. Przez lata uczeń, a potem student ćwiczy się w przygotowywaniu krótkich prac, „analiz z kluczem w tle”, zaniedbując opracowywanie dłuższych, wieloaspektowych, oryginalnych tekstów (szerzej w panelu: Dudzikowa, Bochno, Grzybowski, Kola, Korzeniecka-Bondar, Kin-Wiśniewska, 2013). Taki styl wypowiedzi oducza myślenia, pozbawia przestrzeni do interpretowania i wieloaspektowego oglądu danego zagadnienia. Tymczasem w procesie tworzenia tekstu to właśnie wielokrotny namysł odgrywa kluczową rolę, o czym pisałam szerzej w innym miejscu (Korzeniecka-Bondar, w druku). Powtórzę kilka zawartych tam myśli. Namysł wielokrotny jest procesem myślenia, w którym nie tracimy z pola widzenia sedna sprawy. To myślenie długodystansowe, pogłębione, wielowymiarowe, wymagające czasu - zobowiązujące do zanurzenia się w danej kwestii, bez gwarancji natychmiastowego sukcesu.

Wynika $z$ tego, że autor powinien własny tekst poddawać namysłowi wielokrotnie, biorąc pod uwagę różne aspekty - być krytycznym recenzentem własnej wypowiedzi. Tymczasem autorzy przywiązują się do własnych tekstów, świadomi, jaki nakład pracy towarzyszył ich tworzeniu, i jak dzieci bywają zadowoleni, gdy zakończą proces pisania. Namysłowi nad tekstem nie służy presja czasu i ilości, o której wspominałam na początku mojego artykułu. Profesor psychologii, autor książki Piękny styl. Przewodnik CZŁOWIEKA MYŚLĄCEGo PO SZTUCE PISANIA XXI WIEKU, podkreśla, że tworzenie tekstu jest trudną sztuką, wymagającą interdyscyplinarnej wiedzy, doświadczenia, nabycia pewnej wprawy (Pinker, 2015). W niewielu środowiskach uczelnianych powstają wspólnoty naukowe, w których troszczy się o kształtowanie u młodych adeptów pedagogiki etosu rzetelnej pracy nad własnym warsztatem pisarskim.

Co może zrobić autor, dostrzegając własne błędy pisarskie? Odpowiedź brzmi: podjąć działania samokształceniowe. Znaleźć środowisko, w którym można rozwijać umiejętności tworzenia tekstów i/lub mistrza, od którego można uczyć się sztuki pisania (choćby poprzez czytanie jego prac). Warto także, by otworzył się na informację zwrotną od recenzentów (szczególnie gdy recenzje są negatywne). Rzetelna recenzja pozwala "przekonać się, na ile przystępne i sensowne jest to, co piszemy i co możemy jeszcze poprawić" 
(Lofland i in., 2009, s. 316). Często zawiera trafne wskazówki, krytyczne uwagi, których przemyślenie (ponownie namysł wielokrotny!) może przyczynić się do podniesienia kompetencji pisarskich.

\section{Zaproszenie do lektury}

W związku z tym, że piszę z myślą o młodych adeptach nauki, by uczulić ich na czyhające na nich pułapki oraz zachęcić do tego, by rozwijanie własnego warsztatu pisarskiego traktowali jako całożyciowe zobowiązanie, pozwalam sobie polecić kilka lektur na dobry początek (nie powtarzam ich już w bibliografii, choć je przywoływałam w tekście).

Becker, H. S. (2013). Warsztat pisarski badacza. Przekł. P. Tomanek. Warszawa: Wydawnictwo Naukowe PWN.

Eco, U. (2007). Jak pisać pracę dyplomową. Poradnik dla humanistów. Przekł. G. Jurkowlaniec. Warszawa: Wydawnictwo Uniwersytetu Warszawskiego.

Maćkiewicz, J. (2010). Jak dobrze pisać. Od myśli do tekstu. Warszawa: Wydawictwo Naukowe PWN.

Malinowska, E., Nocoń, J., Żydek-Bednarczuk U. (red.). (2013). Style współczesnej polszczyzny: przewodnik po stylistyce polskiej. Kraków: Towarzystwo Autorów i Wydawców Prac Naukowych Universitas.

Pinker, S. (2015). Piękny styl. Przewodnik człowieka myślącego po sztuce pisania XXI wieku. Przekł. A. Nowak-Młynikowska. Sopot: Wydawnictwo Smak Słowa.

\section{BIBLIOGRAFIA}

Bauer, Z. (2008). Gatunki dziennikarskie. W: Z. Bauer, E. Chudziński (red.), Dziennikarstwo i świat mediów. Nowa edycja. Kraków: Wydawnictwo Universitas.

Dudzikowa, M. (2009). O wciskaniu kitu i rozplenianiu się banału w pedagogicznym dyskursie. W: A. Bogaj, H. Kwiatkowska (red.), Życie i dzieło z ideq wielostronności w tle. Warszawa: Instytut Badań Edukacyjnych, Wydział Pedagogiki Uniwersytetu Warszawskiego.

Dudzikowa, M., Bochno, E., Grzybowski, P.P., Kola, A., Korzeniecka-Bondar, A., Kin-Wiśniewska, M. (2013). Młodzi badacze o swoim doświadczeniu związanym z doskonaleniem warsztatu naukowego i pisarskiego (panel dyskusyjny). Przegląd Badań Edukacyjnych, 16 (1), 113-147.

Eco, U. (1987). Czytelnik modelowy. Przekł. P. Salwa. Pamiętnik Literacki, LXXVIII, 2.

Frankfurt, H. G. (2008). O wciskaniu kitu. Przekł. H. Pustuła. Warszawa: Wydawnictwo Czuły Barbarzyńca.

Giroux, H. A. (1993). Teoria krytyczna i racjonalność w edukacji obywatelskiej. W: Z. Kwieciński, L. Witkowski (red.), Spory o edukację. Dylematy i kontrowersje we współczesnych pedagogiach (s. 103-139). Warszawa, Toruń: IBE, „Edytor”.

Korzeniecka-Bondar, A. (w druku). Namysł wielokrotny nad koniecznością „namysłu wielokrotnego" - narracja o pułapkach pracy nad tekstem naukowym. Tekst przyjęty do: Ł. Michalski, K. Maliszewska (red.), Zeszyty Naukowe Forum Młodych Pedagogów przy Komitecie Nauk Pedagogicznych PAN, t. XXI.

Kulczycki, E. (2013). Jak napisać dobry abstrakt? Pozyskano z: http://ekulczycki.pl/warsztat_ badacza/jak-napisac-dobry-abstrakt/, (data dostępu: 27. 08.2017).

Kwiatkowska, H. (2008). Refleksja ze świata porządku symbolicznego - z warsztatu pracy mocującego się ze słowem (myśli niewykończone). W: R. Wawrzyniak-Beszterda (red.), 
Życie szkoła. Prace dedykowane Profesor Marii Dudzikowej (s. 53-65). Poznań: Garmond Oficyna Wydawnicza.

Lewowicki, T. (2016). Letnia Szkoła Młodych Pedagogów - okolicznościowe refleksje, wspomnienia i przesłania. W: E. Bochno, A. Korzeniecka-Bondar (red.), Naukowa wspólnota uczacych się. XXX-lecie Letniej Szkoły Młodych Pedagogów przy Komitecie Nauk Pedagogicznych PAN (s. 117-127). Białystok: Wydawnictwo Uniwersytetu w Białymstoku.

Lofland, J., Snow, D.A., Anderson, L., Lofland, L.H. (2009). Analiza układów społecznych. Przewodnik metodologiczny po badaniach jakościowych. Przekł. A. Kodrasiewicz, S. Urbańska, M. Żychlińska. Warszawa: Wydawnictwo Naukowe Scholar.

Nawrocki, R. (2016). Zaczarowany umysł w odczarowanej rzeczywistości. Rzecz o irytacji młodego pedagoga. Parezja. Czasopismo Forum Młodych Pedagogów przy Komitecie Nauk Pedagogicznych PAN, 2 (6), 61-73.

Redliński, E. (1973). Konopielka. Warszawa: Ludowa Spółdzielnia Wydawnicza.

Tołwińska, B. (2014). XX-lecie Forum Młodych Pedagogów przy Komitecie Nauk Pedagogicznych Polskiej Akademii Nauk. Parezja. Czasopismo Forum Młodych Pedagogów przy Komitecie Nauk Pedagogicznych PAN, 1, 103-111.

Wojtak, M. (2014). Genologiczna analiza tekstu. Prace Językoznawcze, 16/3, 63-71.

Wojtak, M. (2014a). O gatunkach wypowiedzi i ich prasowych konkretyzacjach. Językoznawstwo: współczesne badania, problemy i analizy językoznawcze, 1(8), 95-105.

Wolny-Zmorzyński K., Kaliszewski A., Furman W. (2006). Gatunki dziennikarskie. Teoria, praktyka, język. Warszawa: Wydawnictwa Akademickie i Profesjonalne.

\section{SUMMARY}

\section{Writing difficulties: comments resulting}

\section{from the reading of texts submitted to be published in "Parezja"}

The aim of the article is to show the writing errors found in the manuscripts sent to be published in "Parezja". Cognitive, structural, pragmatic, stylistic and formal errors have been identified. The author emphasizes the need of multiple reflection during the process of composing the text and the value of scientific communities trying to instil the ethos of hard work on writing skills in pedagogy graduates.

KEY WORDS: academic writing, cognitive errors, formal errors, multiple reflection 